\title{
Filmowe adaptacje baśni i bajek ludowych. Problemy przekładu intersemiotycznego
}

\section{Abstrakt:}

Celem artykułu jest zaprezentowanie problemów dotyczących filmowej adaptacji baśni i bajki ludowej na przykładzie dwóch z trzech sezonów serialu Baśnie i bajki polskie, przygotowanych w latach 2002-2009 przez TV Studio Filmów Animowanych w Poznaniu dla TVP1. Wśród podstawowych problemów tego rodzaju wymieniono łączne traktowanie wszystkich typów baśni (ludowej, literackiej, filmowej) jako swoistego kodu kulturowego, co przekłada się na uproszczenia interpretacyjne oraz unikanie bezpośrednich odwołań do bajki ludowej jako zbyt trudnego i złożonego tekstu kultury wymagającego znajomości szeroko pojętego kontekstu. $\mathrm{Na}$ wybranych przykładach (odcinki pt. Smok Wawelski i Czarne licho) zaprezentowano artystyczne i aksjologiczne konsekwencje powierzchownego podejścia do przekazów ludowych (m.in. estetyzację, karnawalizację, infantylizację, trywializację).

\section{Słowa kluczowe:}

adaptacja, bajka ludowa, Baśnie i bajki polskie, baśń literacka, baśń filmowa, przekład intersemiotyczny

\section{Film Adaptations of Fairy and Folk Tales: Problems of Intersemiotic Translation}

\section{Abstract:}

The main aim of the article is to demonstrate the problematic issues related to film adaptation of fairy and folk tales on the example of two of three seasons of the Baśnie i bajki polskie [Polish Fairy and Folk Tales] series, which were produced between 2002 and 2009 by the TV Studio Filmów Animowanych [TV Studio of Animation Films] for TVP1 (Poland). In the paper, it is indicated that one of such problems is the common predilection to treat different narrative genres (folk tales, literary

* Violetta Wróblewska - dr hab., profesor w Zakładzie Folklorystyki i Literatury Popularnej w Katedrze Kulturoznawstwa Uniwersytetu Mikołaja Kopernika w Toruniu. Jej zainteresowania badawcze obejmują folklor tradycyjny i współczesny, kulturę i literaturę dziecięco-młodzieżową oraz popularną. Kontakt: Violetta.Wroblewska@umk.pl. 
fairy tales, and film fairy tales) as a particular cultural code. This, firstly, leads to the simplification during the interpretation process and, secondly, has such an impact that filmmakers avoid direct references to the folk tale context which, being complex and difficult to research, demands a broad knowledge of folk culture. In the article, using the examples of the series' two episodes (Smok Wawelski [The Wawel Dragon] and Czarne licho [The Black Goblin]), the author presents both the artistic and axiological consequences of a superficial approach to folk tales (carnivalisation, infantilisation, trivialisation, and aesthetisation, among others).

\section{Key words:}

adaptation, folk tale, Baśnie i bajki polskie [Polish Fairy and Folk Tales], literary fairy tale, film fairy tale, intersemiotic translation

R aśnie należą do ulubionych lektur nie tylko dzieci, nie bez powodu więc 3 wiele $\mathrm{z}$ nich przeszło $\mathrm{z}$ obiegu literackiego do filmowego na zasadzie adaptacji, o czym niejednokrotnie już pisano (Konieczna, 2005; Murphy, 2015). Jednak w pracach filmoznawczych - i nie tylko w obrębie tej grupy - istnieje zauważalna tendencja do synkretycznego łączenia rozważań o baśni filmowej, literackiej, jak też bajce ludowej, mimo że wszystkie wymienione konwencje różnicuje m.in. poziom konstrukcyjnej złożoności, styl wypowiedzi, a przede wszystkim zakres podstawowych środków przekazu (audiowizualne w pierwszym wypadku; pismo, czasami wspomagane ilustracją - w drugim; żywa mowa, niekiedy wspierana przez działania pozawerbalne, jak gest czy mimi$\mathrm{ka}-\mathrm{w}$ trzecim). Wspomnianą tendencję synkretycznego traktowania różnych odmian opowieści widać chociażby w funkcjonujących definicjach baśni filmowej, w nieznacznym stopniu różniących się od słownikowych ujęć baśni literackich (Waksmund, 1992, s. 90). Według Anny Marzec (1994):

Konwencja gatunkowa baśni filmowej polega na wykorzystaniu treści fantastycznych, nasyconych cudownością związaną z wierzeniami magicznymi. Znakiem rozpoznawczym baśni filmowej jest bohater swobodnie przekraczający granice pomiędzy światem realnym a światem, w którym działają siły nadprzyrodzone, niezwykłe. W świecie baśni filmowej następuje pomieszanie prawdopodobieństwa $\mathrm{z}$ nieprawdopodobieństwem (fantazja, magia, dziwy), sytuacji prawdziwych z takimi, w które ingerują moce pozaziemskie. Widz ma do czynienia $\mathrm{z}$ antropomorficzną wizją przyrody, zachowującej się na podobieństwo ludzi. Przede wszystkim jednak baśń filmowa utrwala pożądane wartości moralne, chwaląc sprawiedliwość, zwycięstwo dobra nad złem, dobroć i łagodność oraz potrzebę więzi społecznych [...]. W ten sposób proponuje porządek świata, o jakim marzymy. Baśn filmowa może mieć postać filmu animowanego lub aktorskiego (s. 109). 
W przywołanej definicji autorka wymienia cechy typowe dla każdej baśni, jak przenikanie się światów czy obecność magii jako siły sprawczej rzeczywistości przedstawionej, ale jednocześnie odwołuje się do bliżej nieokreślonych „wierzeń magicznych", których występowanie można zaobserwować co najwyżej w bajkach ludowych. We współczesnych utworach rzadko daje się odnaleźć ślady dawnych przekonań, bowiem ich miejsce zajmują inne elementy, np. religijne, w tym chrześcijańskie (modlitwa, różaniec, krzyż), a równie często brak jakiegokolwiek światopoglądowego zakorzenienia. W związku z tym można w odniesieniu do baśni mówić jedynie o daleko posuniętej fantastyczności świata przedstawionego, i to w przekazie zarówno literackim, jak i filmowym.

Pomijanie odmienności opowieści w rozważaniach filmoznawców może być pobocznym skutkiem działań samych twórców baśniowych adaptacji, którzy nie zawsze wskazują konkretne źródła swojego natchnienia. Zazwyczaj scenarzyści i reżyserzy nawiązują do powszechnie znanych wątków i nie wydaje się im zasadne odwołanie do konkretnej realizacji, która i tak odbiorcom nie będzie znana. Częściej bazą adaptacji stają się wątki obiegowe, powszechnie znane, niż konkretne ich warianty. W efekcie w pracach dotyczących problematyki baśni filmowej jedynie wskazuje się nazwę i numer wątku zgodnie z międzynarodową ich typologią, np. T 333 „Czerwony Kapturek” (ATU 333 „The Glutton [Red Riding Hood]”), a rozważania ogranicza się do prezentacji zmian fabularnych i związanych z tym reinterpretacji samej opowieści (Short, 2015, s. 147-150).

Powodów braku bezpośrednich odniesień do bajki ludowej w samych dziełach filmowych, a tym samym w traktujących o nich opracowaniach, poza obiegową znajomością popularnych fabuł, może być kilka i wydają się one oczywiste. Po pierwsze, większość reżyserów nie podejmuje się przekładu bajki ludowej na język filmu, skoro ma jej doskonałe, popularne na całym świecie odpowiedniki literackie. Obecność nazwisk znanych pisarzy, jak Hans Christian Andersen czy bracia Jakub i Wilhelm Grimm, lub przywołanie - w zapowiedzi bądź w podtytule produkcji - tytułów ich dzieł, jak Mała syrenka (Andersen, 1837/2005) czy Roszpunka (Grimm, Grimm, 1812/2004), gwarantuje zainteresowanie widzów, co może przełożyć się na sukces komercyjny. Po drugie, twórca filmu, decydując się na przekład tego rodzaju, zmuszony byłby sięgnąć do zapisanych opowieści z oralnych źródeł, które to narracje obecnie

1 Odwołania do międzynarodowej systematyki wątków Hansa-Jörga Uthera (2004/2011), w której skrót ATU odsyła do systematyki, a numer z nazwą do konkretnego wątku. W Polsce odpowiada temu systematyka Juliana Krzyżanowskiego (1962-1963), gdzie T z numerem oraz nazwą oznacza typ i konkretny wątek. 
nie należą do popularnych i rzadko bywają wznawiane, gdyż wyparły je literacko opracowane antologie. Po trzecie, przy rezygnacji z ludowego materiału na rzecz literackiego dzieła zostaje wyeliminowanych wiele problemów rodzących się przy adaptacji tekstu oralnego na potrzeby ekranu. Zdaniem Marty Wójcickiej $(2018)^{2}$, tego rodzaju adaptacja ma charakter intersemiotyczny, jest wielosystemowa, a przez to generuje liczne działania i trudności:

Proces adaptowania (np. utworu folkloru na film) polega [...] na dostosowaniu utworu wykreowanego $\mathrm{w}$ jednym medium do potrzeb odmiennego medium [...]. Adaptacja ujmowana jest jako proces przechodzenia z jednej struktury znakowej (np. werbalnej, oralnej formy bajki) w inną strukturę znakową (np. audiowizualną, filmową wersję bajki). Adaptacja (np. filmowa, teatralna, telewizyjna) może zostać uznana za nietypowy i intrygujący przypadek przekładu wielosystemowego w podwójnym znaczeniu: (1) ze względu na różnicę systemów semiotycznych (język werbalny - język ruchomych obrazów), (2) ze względu na multikodowość docelowego języka adaptacji (język ruchomych obrazów angażuje i wykorzystuje w procesie komunikowania wiele różnych subkodów) (s. 16-25).

W praktyce oznacza to m.in. konieczność przekładu języka gwarowego na język artystyczny czy zastąpienie realiów kulturowych, niezrozumiałych dla współczesnego odbiorcy, tymi, które są mu znane lub bardziej przystają do obowiązujących norm. Dotyczyć to może np. obrzędów, codziennych zajęć (m.in. związanych $\mathrm{z}$ hodowlą zwierząt, uprawą pól) czy międzyludzkich relacji usankcjonowanych przez kulturę tradycyjną, a nieakceptowanych współcześnie, jak postawy ostracystyczne wobec starców i osób z niepełnosprawnościami (np. eliminowanie z grupy, nękanie werbalne i fizyczne, o czym piszą Kalniuk, 2014, i Zadurska, 2017). Większość tego typu kwestii baśnie literackie znoszą lub łagodzą na tyle, że nie wywołują kulturowej dezorientacji i nie wzbudzają oburzenia odbiorców, a o takie reakcje nietrudno, gdy mowa o surowych przekazach oralnych. Wystarczy przywołać toczące się do czasów współczesnych dyskusje na temat baśni braci Grimm (które przecież, choć miały ludowe korzenie, i tak poddano literackiej obróbce, a także zmianom w kolejnych wydaniach). Dotyczyły one tego, czy powinno się dzieciom udostępniać obecne $\mathrm{w}$ tradycyjnych narracjach sceny makabryczne, jak okaleczanie i mordowanie ludzi (torturowanie niewinnych ofiar, surowe karanie przestępców), czy też należy je rugować (usuwać, modyfikować, łagodzić ich wymowę) ze względu na nieprzewidywalne w skutkach konsekwencje natury psychicznej, które pod ich

2 Zob. także hasło w wersji słownika on-line (Wójcicka, 2016-2018). Autorka odwołuje się do ustaleń Marka Hendrykowskiego (2013). 
wpływem mogą wystąpić u młodych odbiorców (Osterloff, 1946; Pieciul-Karmińska, 2009-2010).

Przy filmowej adaptacji bajki ludowej wiele problemów nastręczać mogłaby również charakterystyczna dla tekstów oralnych, nieco nużąca z dzisiejszej perspektywy narracja, zwykle monotonna, sprawozdawczo-informacyjna, prowadzona na zasadzie stylu addytywnego (wyliczenie elementów świata przedstawionego zamiast ich opisów) i formulicznego (utrwalone struktury zdaniowe otwierające, zamykające i spajające przekaz), a także nieznaczna liczba dialogów (Lüthi, 1968/1982, s. 36-40). Pomijam w tym miejscu rozważania na temat wykonywania bajek przez utalentowanych gawędziarzy, którzy mogli wzbogacać swe występy różnego typu środkami werbalnymi i niewerbalnymi (np. mimiką, gestykulacją, interakcjami ze słuchaczami), o czym niejednokrotnie pisano (Smolińska, 1987). Adaptacja filmowa tekstu ludowego, bez znajomości zasad jego wykonywania, stanowiłaby nie lada wyzwanie dla reżysera, który podjąłby się tego typu artystycznego działania. Oralne opowieści zdecydowanie częściej się nagrywa i prezentuje w formie audiobooków, na stronach internetowych poświęconych kulturze regionalnej, np. kaszubskiej (Zrzeszenie Kaszubsko-Pomorskie, 2019), bądź popularyzujących formę bajania, jak cykl $Z$ naszej bajki na stronie projektu Wolne Lektury (2011).

Przywołane problemy najlepiej obrazuje powstały w latach 2002-2017 cykl filmowych adaptacji pt. Baśnie i bajki polskie zrealizowany dla TVP1 przez TV Studio Filmów Animowanych w Poznaniu i dostępny na kanale YouTube. Jak można się dowiedzieć z oficjalnej strony TVP ABC (b.d.), to:

[...] polski serial animowany, który powstał w latach 2002-2005 [mowa o pierwszym sezonie; w 2007-2009 wyprodukowano drugi, a w 2013-2017 - trzeci] w Telewizyjnym Studiu Filmów Animowanych w Poznaniu, pod okiem Ewy Sobolewskiej. Serię tworzyło wielu znakomitych polskich artystów: grafików, reżyserów, scenarzystów, muzyków... m.in.: Zbigniew Kotecki, Witold Giersz, Robert Turło, Jacek Adamczak, Andrzej Gosieniecki, Zbigniew Kozub, Aniela Lubieniecka, Krzysztof Napierała, Artur Wrotniewski, Hieronim Neumann i Jacek Kasprzycki. Serial został oparty na motywach znanych polskich baśni, bajek i legend. Dzięki swojej otwartej formie poszczególne części różnią się między sobą stylistyką i estetyką, tym samym pokazując bogactwo artystyczne i różnorodność interpretacyjną. Seria zdobyła wiele nagród na polskich i międzynarodowych festiwalach ${ }^{3}$.

M.in. w Kairze i Bratysławie (Krawiec Niteczka - Neumann, Gosieniecki, 2005), Houston (O królewnie zaklętej w żabę - Jabłońska, Turło, 2005; Dwanaście miesięcy - Chybowicz-Brożyńska, Kotecki, 2004), Moskwie (Zaczarowane pantofelki - Lubieniecka, 2005) i Nowym Jorku (Lodowa góra - Lubieniecka, Turło, 2003) - zob. TVP Info (2010). 
Przywołany cykl - łącznie powstały trzy serie, każda po trzynaście odcinków trwających około trzynastu minut (TV Studio Filmów Animowanych, 2019) - oddaje istotę problematycznych zjawisk związanych z procesem adaptacji, o czym była mowa, zaczynając od wyboru przykładów, poprzez sam rodzaj adaptacji, a kończąc na wynikających z tego faktu trudnościach formalnych i semantycznych.

Większość zaproponowanych przez TVP1 odcinków serii Baśnie i bajki polskie (w artykule zajmuję się pierwszymi dwoma sezonami) powstała na podstawie literackich adaptacji bajek ludowych. Twórcy serialu nierzadko bardzo swobodnie potraktowali wyjściowy materiał, co naturalne przy tego typu procesach ${ }^{4}$. Informacje o pierwowzorze umieszczono $\mathrm{w}$ finalnej części każdego z odcinków, w tzw. napisach końcowych, chociaż nie wskazano odniesień do konkretnych wątków ludowych (wprowadzam je w nawiasach zgodnie z systematyką Krzyżanowskiego). Dzięki zamieszczonym danym możemy się dowiedzieć, które z polskich baśni spotkały się z uznaniem reżyserów cyklu:

- O Bartku doktorze (Lubieniecka, Kukuła, 2003) zrealizowano na podstawie tak samo zatytułowanego utworu Hanny Januszewskiej (1952; T 332 „Kuma-Śmierć”);

- Lodowa góra (Lubieniecka, Turło, 2003) nawiązuje do Bajki o królewnie Marysi, o czarnym łabędziu i o lodowej górze Kornela Makuszyńskiego (1916/1958a; kontaminacja wątków T 900 „Dumna królewna”, T 530 „Szklana góra”, T 451 „Siedem kruków”);

- Żywa woda (Lubieniecka, Giersz, 2003) jest adaptacją Sobotniej Góry Romana Zmorskiego (1852; T 551 „Wyprawa po żywą wodę”);

- Dwanaście miesięcy (Chybowicz-Brożyńska, Kotecki, 2004) stworzono na motywach $O$ dwunastu miesiącach Janiny Porazińskiej (1952a; T 480B „Dwie siostry i miesiące”);

- O królewnie zaklętej w żabę (Jabłońska, Turło, 2005) - na motywach bajki Antoniego Glińskiego (1853; T 402 „Królewna-żaba”);

- odcinek Złota jabłoń (Jasińska-Koronkiewicz, 2008) jest adaptacją identycznie zatytułowanej baśni Hanny Januszewskiej (1955; swobodna przeróbka wątku bajki magicznej T 511 „Macocha i pasierbica”);

4 Problem adaptacji bajki ludowej jako tworzywa artystycznego szerzej omówiła Jolanta Ługowska (1981). 
- O Zefliku i smoku (Kurek, Kukuła, 2009) to część serii powstała na kanwie baśni O tym, jak głupi Zeflik był mądrym Zeflikiem Gustawa Morcinka (1958a; T 300 „Królewna i smok”).

Kolejne odcinki mają jeszcze inne źródła:

- Szklana góra (Adamczak, 2002) powstała na motywach baśni Bronisławy Ostrowskiej (ok. 1923; bardzo swobodna przeróbka T 530 „Szklana góra");

- Złota kaczka (Lubieniecka, Kasprzycki, 2002) - na motywach Złotej kaczki Artura Oppmana (1925b; T 464 „Czarna królewna”);

- Szewczyk Dratewka (Lubieniecka, Wrotniewski, 2003) to adaptacja Szewczyka Dratewki Porazińskiej (1952b; T 554 „Wdzięczne zwierzęta”);

- Bazyliszek (Jabłońska, Kukuła, 2004) powstał na podstawie Bazyliszka Oppmana (1925a; wątek podaniowy T 6510 „Bazyliszek”);

- odcinek Zaczarowane pantofelki (Lubieniecka, 2005) - na kanwie baśni o złej córce, jednej z opowieści wchodzących w skład Prządek Narcyzy Żmichowskiej (1845/1907);

- Krawiec Niteczka (Neumann, Gosienicki, 2005) to adaptacja utworu O tym, jak krawiec, pan Niteczka, został królem Makuszyńskiego (1916/1958b; brak pierwowzoru, luźne nawiązania do humoresek ludowych);

- Zuzankę i utopce (Kurek, Martini-Madej, 2008) stworzono na podstawie O tym, jak Zuzanka poszła w kumy do utopców Morcinka (1958c; T 504 „Dary krasnoludków”; zamiast krasnoludków występuje utopiec - bohater podania wierzeniowego T 4060 „Topielec”);

- część zatytułowana Zimowe wróżki (Jabłońska, Dudek, 2008) stanowi adaptację O Klaruni-koronczarce i zimowych wróżkach Ewy Szelburg-Zarembiny (1966; brak bezpośrednich odniesien do wątków ludowych; cechy bajki magicznej);

- Kozucha kłamczucha (Lesisz, Kukuła, 2008) i Pasterz tysiąca zajęcy (Dyksińska, Krzysik, 2009) to odcinki odwołujące się do identycznie zatytułowanych baśni Porazińskiej (1939, 1955; pierwsza realizuje wątek komiczny T 2015 „Koza obdarta”, druga to kontaminacja wątków bajki magicznej T 570 „Głupiec pasie zające” i bajki komicznej T 1921 „Kłamstwa nad kłamstwami”);

- Bursztynowa korona (Kurek, Czarzasty, 2009) opiera się na motywach tak samo zatytułowanej bajki Hanny Zdzitowieckiej (1972; brak

5 Zob. także Gołębiowska-Suchorska (2018). 
odpowiednika ludowego wątku; utwór ma formę podania ajtiologicznego o pochodzeniu mikołajka nadmorskiego);

- Szewc Kopytko i kaczor Kwak (Gosienicki, 2009) to przekład analogicznie zatytułowanego utworu Makuszyńskiego (1916/1958c, brak pierwowzoru, luźne nawiązania do humoresek ludowych);

- Dar Skarbnika (Jabłońska, Turło, 2009b) stanowi swobodną przeróbkę O tym, jak górnik Maślok kramarzył ze Skarbnikiem Morcinka (1958b; wątek legendy ludowej T 754 „Pieniądze nie dają szczęścia”).

Nieliczne z odcinków nie mają literackiego źródła, a jedynie sygnalizuje się ich ludowość w komentarzu, czasami podaje także tytuł bliżej nieokreślonego pierwowzoru:

- O kowalu i diable - „na motywach legendy wielkopolskiej O Maćku Borkowicu i diable Borucie" (Adamczak, 2004; luźne nawiązanie do wątku bajki magicznej T 330A „Kowal i diabli [Śmierć na gruszy]”);

- Smok Wawelski - „na motywach ludowych” (Jabłońska, Dudek, 2004);

- Król kruków - „na motywach bajki ludowej Trębacz ratuszowy i król kruków" (Adamczak, 2008);

- Korale czarownicy - „na motywach bajki ludowej” (Lubieniecka, 2008);

- Czarne licho również, jak Smok Wawelski, „na motywach ludowych” (Jabłońska, Turło, 2009a; T 651 „Diabeł parobkiem”; zamiast diabła występuje licho).

- Poznańskie koziołki - „na motywach bajki ludowej” (Adamczak, Gałązkowski, 2009).

Nie zawsze tego typu informacje są pełne, ale niektóre $\mathrm{z}$ realizacji poprzez wskazanie w napisach końcowych tytułu rzekomo ludowej narracji pośrednio odwołują do już istniejących wersji literackich, które bez trudu można odnaleźć w sieci czy popularnych antologiach baśni i legend. O kowalu i diable (Adamczak, 2004) nawiązuje do jednej z opowieści z tomu O Maćku Borkowicu i diable Borucie oraz inne podania i legendy wielkopolskie opracowanego przez Stanisława Świrkę (1984), a Trębacz ratuszowy i król kruków - do analogicznie zatytułowanego (z dopiskiem „legenda wielkopolska”) utworu Czesława Kędzierskiego (1929/1989)6. Inne odcinki także mają swe bardziej lub mniej jawne odniesienia, jak Korale czarownicy (Lubieniecka, 2008), zna-

6 Skróconą wersję opowieści Czesława Kędzierskiego można znaleźć na stronach internetowych, m.in. dotyczących Poznania, np. Kwiatkowska (2017). Wersję tę wykorzystali w swych zbiorach podań również Stanisław Świrko i Krzysztof Kwaśniewski. Dzieje wątku, w tym wskazanie najstarszej pisanej realizacji, Trębacza na ratuszu. Ballady z XVII. wieku 
ne pod tym samym tytułem z opracowania Macieja Leszczyńskiego (b.d.), jak też z wcześniejszej wersji mazurskiej Czarownica znad Bełdan Klemensa Oleksika (1959). Trudniej jednoznacznie wskazać źródła opowieści o poznańskich koziołkach czy o Smoku Wawelskim, których dzieje niejednokrotnie były opracowywane przez pisarzy nie tylko dla dzieci, w pierwszym wypadku np. Krzysztofa Kwaśniewskiego, Tadeusza Kraszewskiego, Wandę Chotomską, Stanisława Świrkę, a w drugim - przez Józefa Ignacego Kraszewskiego, Janinę Porazińską czy ponownie Chotomską. Jeszcze bardziej problematyczna w zakresie ustalenia genezy jest część o czarnym lichu, chociaż jeśli weźmie się pod uwagę fakt, że podstawą odcinka jest wspomniany wątek „Diabeł parobkiem", to i w tym wypadku można odnaleźć literackie opracowania, np. Stanisława Dzikowskiego, Romana Zmorskiego czy Antoniego Glińskiego, ale żadne $\mathrm{z}$ dzieł ze względu na znaczne rozbieżności formalne i semantyczne nie jest źródłem filmowej baśni ${ }^{7}$.

Wybór literackich przykładów, stanowiących podstawę wskazanych filmów z pierwszej grupy, nie jest tu przypadkowy. Poza nadrzędnym kryterium narodowym, które okazało się kluczowe w selekcji pierwowzorów, niemal wszystkie teksty, jednowątkowe, wyrastające w mniejszym lub większym stopniu $\mathrm{z}$ folkloru, należą do kanonu bajki i baśni polskiej, a ich twórcami są wybitni twórcy literatury dla dzieci, zarówno z XIX, jak i z pierwszej połowy XX wieku. Cechą łączącą wymienione utwory jest ich przystosowanie do możliwości odbioru przez dziecięcego czytelnika, w tym pod kątem wyzwań dydaktycznych. $Z$ tego też powodu są to zwykle opowieści nieskomplikowane, o dynamicznej akcji, z wyrazistym przesłaniem moralnym, a niekiedy i patriotycznym, jak w wypadku Sobotniej góry Zmorskiego (Krzyżanowski, 1977, s. 738-739). Istotnym komponentem wielu z nich jest również komizm prosty, przejawiający się w ludycznej prezentacji postaci, zdarzeń czy sytuacji, co wzmaga atrakcyjność przekazu, wpisując go w preferowany przez kilkuletnich odbiorców karnawałowy nurt sztuki. Zresztą żywioł zabawowy został utrzymany w całej serii animowanych bajek polskich, co jest zauważalne nawet w planie plastycznym, bowiem wszystkie dobre postaci są ładne, sympatyczne, wesołe, złe zaś, nawet

w trzech aktach Zofii Zielewiczówny (1914), przedstawił Paweł Cieliczko (b.d.) w tekście Legenda o trębaczu ratuszowym i królu kruków, dostępnym na portalu Poznańskie Legendy.

7 Niezależnie od stopnia szczegółowości danych dotyczących genezy ekranowego przekazu, we wszystkich wypadkach wskazano osobę, która dokonała tekstowej adaptacji oraz pełniła funkcję autora scenariusza i dialogów, nierzadko również pomysłodawcy oprawy plastycznej, rzadziej reżysera. Wśród twórców przekładających teksty bajek na język filmu najczęściej wymienia się: Monikę Chybowicz-Brożyńską, Zbigniewa Koteckiego, Grażynę Dyksińską, Jacka Adamczaka, Anielę Lubieniecką. 
demony i potwory - przerysowane, karykaturalne, nierzadko niezdarne, niepotrafiące nieraz sprostać codziennym wyzwaniom, a przez to wywołujące nie strach, lecz śmiech.

Równie konsekwentnie we wszystkich odcinkach serii TVP1 budowany jest sielankowy obraz wsi jako miejsca akcji. Dominują chaty kryte strzechą, ubogie, ale czyste, kolorowe, wyposażone w ładne, drewniane meble i niezbędne sprzęty. Przed domami zwykle znajdują się ogródki pełne kwiatów i warzyw. Dookoła rozciągają się przestrzenie pól i łąk, w oddali widać las, a niekiedy kościół i dwór bądź zamek. Bywa, że obraz utrzymany jest w szarościach, co ma podkreślić biedę wieśniaka, a później staje się wielobarwny, gdy życie wieśniaka ulega poprawie, jak w baśni O Zefliku i smoku (Kurek, Kukuła, 2009). Reżyserzy przedsięwzięcia odwołują się więc do stereotypowo pojmowanej przeszłości, budowanej na modelu hierarchicznym, klasowym, z wyraźnym podziałem społecznych ról. Chłop ciężko pracuje na roli, swe pole orze drewnianym pługiem ciągniętym przez konia lub krowę, gdy w tym czasie pan spędza czas na zabawach i biesiadach w zamku. Równie tradycyjnie ujęty jest podział ról płciowych, gdyż w dominującej części odcinków aktywnymi bohaterami są chłopcy, a dziewczęta odgrywają bierną rolę ofiar przemocy domowej (np. pasierbica nękana przez macochę) lub panien na wydaniu, czekających na wyzwoliciela, który odmieni ich los (Śmiałowicz, 2016, s. 467-468). Do nielicznych wyjątków należą opowieści o samodzielnych bohaterkach, jak o Klaruni-Koronczarce, ale i w tym wypadku aktywność dziewczynki jest bardzo ograniczona, bowiem sprowadza się do zdobycia umiejętności pozwalających jej robić najpiękniejsze koronki na świecie, co wpisuje się w schematyczny podział ról kulturowych (zajęcia uchodzące za męskie i kobiece).

Klimat umownej dawności, poza archaicznym obrazem wsi i zasad jej funkcjonowania, w tym metod pracy, buduje również początkowa partia narracji, nawiązująca do formuł inicjalnych bajek ludowych. Każdy odcinek rozpoczyna narrator, który głosem $\mathrm{z}$ offu, niczym gawędziarz wprowadzający słuchacza w świat bajki, wygłasza formułę: „Dawno, dawno temu, a może nie tak dawno, za górami, za lasami, a może gdzieś niedaleko...”, a potem następuje właściwa historia. W dalszej części głos zostaje oddany bohaterom, których wypowiedzi dominują do końca filmu, czego nie spotyka się w przekazach ludowych - w nich protagonista mówi rzadko i to zwykle w scenach kluczowych dla akcji. Narrator sporadycznie się wypowiada, chyba że sygnalizuje zmianę miejsca akcji lub wprowadza nowego bohatera. Zdecydowanie częściej, chociaż nie jest to regułą, ponownie ujawnia się w finalnej części narracji - w sytuacji gawędzenia, np. „Szewczyk Dratewka został królem i panował długo i szczęśliwie” (Lubieniecka, Wrotniewski, 2003), „I do dziś żyją szczęśliwi - Zazulka 
i Kozucha, już nie kłamczucha. Za górami, za lasami, a może gdzieś niedaleko...” (Lesisz, Kukuła, 2008), „Tak oto czarny parobek został u chłopa. Czuł się tu lepiej niż na bagnach, a poza tym wiecie przecież, że nigdy nie lubił sypiać w dzień” (Jabłońska, Turło, 2009a), „I żyli długo i szczęśliwie” (Lubieniecka, Turło, 2003). Warto też podkreślić, że w celu uatrakcyjnienia odbioru wykorzystano $\mathrm{w}$ animacjach różne rozwiązania plastyczne - od tradycyjnych po nowoczesne, np. sceny utrzymane w duchu obrazów malowanych akwarelami w Krawcu Niteczce (Neumann, Gosieniecki, 2005) i Szklanej górze (Adamczak, 2002) lub odwołujące się do grafiki gier komputerowych, jak postaci w Bazyliszku (Jabłońska, Kukuła, 2004). Świadectwem unowocześnienia treści przekazów, poza uwspółcześnieniem języka, jest z kolei wprowadzenie w świat baśni elementów znanych dzieciom z codzienności, jak telefon komórkowy, komputer, ekipa filmowa czy laboratorium.

W wypadku adaptacji konkretnych baśni literackich nie ma problemu z określeniem stopnia przetworzenia oryginału, gdyż wystarczy porównać filmową wersję z jej pierwowzorem wskazanym w napisach końcowych. Inaczej jest w wypadku pięciu baśni filmowych powstałych, wedle zapewnień twórców, na motywach czy wątkach ludowych. W żadnym odcinku nie wskazano konkretnego źródła przekazu stanowiącego podstawę adaptacji, a w innych jedynie w nazwach podkreślono regionalny charakter opowieści: „na motywach legendy wielkopolskiej O Maćku Borkowicu i diable Borucie" (Adamczak, 2004) czy Poznańskie koziołki (Adamczak, Gałązkowski, 2009). W przywołanych przykładach mimo wskazówek w napisach końcowych bez trudu daje się odnaleźć literackie pierwowzory. Można jednak zakładać, że znaczny stopień przetworzenia oryginału mógł zadecydować o rezygnacji z podania przez twórców filmu bliższych danych identyfikujących utwór, chyba że w grę wchodziły też ograniczone prawa autorskie do pierwowzoru lub odwołania do obiegowych wyobrażeń na temat wątków.

Zasygnalizowanie ludowości źródła w napisach końcowych niejednokrotnie ma charakter konwencjonalny. Nie kryje się za tym przekaz oralny, lecz obiegowe wyobrażenia na jego temat, np. o poznańskich koziołkach czy Smoku Wawelskim. Wiadomo, że nie były to postaci wywiedzione z chłopskiego imaginarium, lecz bohaterowie podań miejskich (zwanych potocznie legendami) powiązani z empirycznie weryfikowalną przestrzenią - ratuszem w Poznaniu i smoczą jamą pod Wawelem. Narracje o tych lokalnych atrakcjach funkcjonowały głównie wśród mieszkańców miasta, a nie wsi, więc w tym wypadku sugerowaną przez twórców filmowej baśni ludowość można traktować jedynie bardzo szeroko jako plebejskość, odnoszącą się do najniższych warstw społecznych. 
W tradycji ludowej postać potwora $\mathrm{z}$ wawelskiej jamy występuje sporadycznie, co wiąże się zapewne z jej pochodzeniem - kościelnym lub dworskim (V. Wróblewska, 2018a). Jego dzieje w różnych wariantach utrwalili polscy kronikarze, szczególnie epoki średniowiecza, a zmodyfikowali i spopularyzowali pisarze kolejnych epok, w tym twórcy literatury dla dzieci. XIX-wieczni etnografowie zainteresowani pozyskaniem opowieści o bajecznych dziejach Polski mimo licznych starań nie odnotowali historii Smoka Wawelskiego w terenie, więc uciekali się do streszczeń z dostępnych kronik lub cytowali podania $\mathrm{z}$ antologii literacko opracowanych wątków, m.in. Lucjana Siemieńskiego (1845):

Pod górą Wawel, gdzie dzisiaj stoi zamek krakowski, był smok wielki, który troje dobytka naraz zjadał, także i ludzi kradł i jadł; przeto musieli mu dawać obrok, każdy dzień troje cieląt albo baranów. Kazał tedy Krok nadziać skórę cielęcą siarką, a przeciw jamie położyć rano: co uczynił za radą Skuba szewca niejakiego, którego potem dobrze udarował i opatrzył. On wyszedłszy z jamy, mniemał by ciele pożarł razem: gdy to w nim tlało tak długo, pił wodę aż zdechł. Jest jeszcze jego jama pod zamkiem, Smoczą jamą zwana (s. 1) .

Zaproponowana przez TVP filmowa adaptacja opowieści o Smoku Wawelskim (Jabłońska, Dudek, 2004) bardzo luźno nawiązuje nawet do literackiej wersji, na co wskazują liczne nowe detale. W odcinku pokonanie bestii mieszczanie zawdzięczają nie Krakowi czy szewcowi, lecz dwom synom szewca, o imionach Smykałka i Cholewka. W filmowej opowieści występuje nieobecna w znanych wersjach o smoku królewna Wanda, popularna bohaterka innego krakowskiego podania (V. Wróblewska, 2018b). Dziewczyna jednak nie rzuca się w nurt Wisły w związku z groźbą wyjścia za maż za niemieckiego rycerza, lecz zgodnie $\mathrm{z}$ tradycją słowiańską na wodę puszcza wianek $\mathrm{z}$ kwiatów, licząc na udane zamążpójście, chociaż to działanie nie wydaje się adekwatne do wieku bohaterki, gdyż wygląda ona i zachowuje się jak dziewczynka. Smok także nie jest typowym smokiem, mimo że takie sprawia wrażenie. Nie pożera owiec ani ludzi, lecz je warzywa, owoce, kanapki i obwarzanki. Ponieważ jego apetyt wzrasta, wkracza do miasta i zjada wszystko, co lubi. A ma się czym żywić, bowiem na miejskich straganach znajdują się warzywa i owoce, w tym zaskakujące jak na opowieść odnoszącą się do dawnych czasów banany.

Równie interesująco przedstawiają się sposoby pokonania smoka. Różni wezwani doradcy mają nietypowe propozycje - historyk sugeruje związek

8 Sam Siemieński z kolei swobodnie korzystał z kroniki Bielskiego (1551). 
małżeński smoka z królewną Wandą, a specjalista od dużych zwierząt, podobnie jak treser z cyrku - ćwiczenia, które jednak poza chwilowym zajęciem uwagi intruza nie przynoszą pożądanego rezultatu. Podrzucona bestii przez dzieci szewca barania skóra wypełniona siarką, fasolą, prochem i grochem, aby potwór ją zjadł i w efekcie pękł, także nie zmienia sytuacji, gdyż zwierz jest wegetarianinem i pozostawia nietknięte zatrute danie. Dopiero napełniona podobnymi składnikami dynia przynosi rozwiązanie problemu, gdyż smok ją zjada, a spragniony pije wodę i niczym balon unosi się w powietrze. W finale narrator stwierdza: „I tak kończy się ta historia. Wejście do smoczej jamy na rozkaz króla Kraka zamknięto żelazną kratą, która do dzisiaj tkwi w wawelskim wzgórzu" (Jabłońska, Dudek, 2004).

Oparta rzekomo na wersji ludowej adaptacja filmowa w większym stopniu niż do oralnych wariantów nawiązuje do współczesnych literackich baśni dla dzieci, w których smok pokazywany jest jako istota mało groźna, niekiedy zabawna i przyjacielska. Przesunięcia znaczeń, jakie wprowadzono w filmowej realizacji fabuły wątku, wiodą - podobnie jak w literaturze piękniej - „od potworów do znaków pustych” (Bolecki, 1989; V. Wróblewska, 2014). Można w tym wypadku mówić nawet o zjawisku infantylizacji'. Smok okazuje się zagrożeniem pozornym, w końcu zjada jedynie warzywa i owoce, a nie ludzi, z radością przygląda się kolorowym motylkom i żongluje obwarzankami. W finale łagodne jest jego usunięcie z ludzkiej ekumeny - po wypiciu wody po prostu unosi się $\mathrm{w}$ powietrze i odlatuje wraz $\mathrm{z}$ bocianami. Bohaterowie - pomysłodawcy wyzwolenia grodu - wcale nie kwapią się do ślubu, zwłaszcza że podobnie jak Wanda są dopiero nastolatkami, a nie kawalerami szukającymi żon, a jeden $\mathrm{z}$ nich nawet twierdzi, że nie zamierza się $\mathrm{w}$ ogóle żenić. W ostatniej scenie Wanda i synowie szewca biegną razem się bawić poza murami zamku.

Poza zmianami fabularnymi, w których widoczna jest wspomniana skłonność do infantylizacji, występuje typowa dla twórczości dla dzieci karnawalizacja. Dowodzą tego zarówno postaci tresera, cyrkowców, jak i popisy żonglerskie smoka, a także wprowadzanie w historię elementów współczesnych, jak młodzieniec w T-shircie, w krótkich spodenkach, w czapce z daszkiem i klapkach, który przez lupę obserwuje smoka. Również sceneria zdarzeń bardziej kojarzy się z wesołym miasteczkiem niż miejscem grozy, o czym świadczy miniaturyzacja kamieniczek, dominacja pogodnych, wyrazistych kolorów, pstrokate stroje mieszkańców, jak też słyszalna w tle pogodna muzyka.

9 Ryszard Waksmund (2000, s. 219) mówi o infantylizacji bajek literackich. 
W momentach ataku smoka na miasteczko dźwięki towarzyszące zdarzeniom przybierają charakter muzyki cyrkowej, co doskonale konweniuje z obrazem ${ }^{10}$. Karnawałowość świata przedstawionego budują dodatkowo wspomniane elementy nowoczesne, nieprzystające do świata baśni, jak cyrk, szorty czy lupa. W całym cyklu widoczna jest zresztą zabawa motywami bajkowymi i schematami fabularnymi, gdyż obok typowego konfliktu między bohaterem a antagonistą, stanowiącego trzon każdej tradycyjnej bajki magicznej, pojawiają się bez głębszego uzasadnienia postaci z innych bajek (bądź się o nich wspomina), jak Czerwony Kapturek, Baba Jaga, rozbójnicy.

Podobny rodzaj adaptacji prezentuje inny „ludowy” odcinek - Czarne licho (Jabłońska, Turło, 2009a). Baśń filmowa wyrastająca $\mathrm{z}$ wątku bajki magicznej o diable, który został parobkiem, ponieważ zjadł ostatnią posiadaną przez biednego chłopa kromkę, również wprowadza odbiorcę w świat karnawału. Zamiast diabła pojawia się licho, znany z tradycji ludowej bliżej nieokreślony demon leśny, swoisty odpowiednik czarta. W omawianym odcinku występuje w zasadzie nie jeden, ale wiele tego typu demonów harcujących na bagnie w rytm muzyki country. Kiedy licho kradnie chleb i mleko ubogiego chłopa, musi „naprawić” swój zły uczynek. Przez pomyłkę dostaje jednak od swego „szefa” (tak jest nazywany naczelny demon bagna) miksturę na pracowitość zamiast na lenistwo, w efekcie czego błyskawicznie i efektywnie działa, przysparzając biedakowi majątku. Kiedy wraca na mokradła i okazuje się, że - według jego „szefa” - jego zaangażowanie poszło na marne, gdyż wcale nie miało doprowadzić do wzbogacenia biedaka, ale pogorszyć jego stan majątkowy, rezygnuje $\mathrm{z}$ bycia lichem i podejmuje decyzję o pozostaniu na służbie u chłopa.

Cała opowieść, mimo że wyrasta z bajki magicznej z elementami podania wierzeniowego (występowanie istoty demonicznej), w wersji filmowej przeradza się w baśń humorystyczną, podobnie jak historia Smoka Wawelskiego. Komizm budowany jest, analogicznie jak w całym cyklu, prostymi metodami. Postaci - różnego typu licha - przypominają znane z wielu kreskówek potwory, niekształtne ludziki z kolorowej plasteliny, które niczym niesforne dzieci przewracają się, kapryszą i psocą. Towarzyszą temu chwyty znane z komedii omyłek, jak kilkukrotna przypadkowa zamiana eliksirów wywołująca niezamierzone efekty, co przekłada się np. na zwiększenie prędkości działania czarnego licha (zabieg przyspieszenia ruchu taśmy). Poprzez zmianę prezentacji świata przedstawionego i przebiegu zdarzeniowego

10 O roli muzyki w filmie dla dzieci zob. J. Wróblewska (2018, s. 145-163). 
zakłóceniu jednak podlega aksjologia baśni. W pierwowzorze schemat fabuły jest następujący:

I. diabeł i biedak. diabeł kradnie lub rzuca w błoto kawałek chleba, przeznaczony na posiłek biednego chłopa (drwala); z wyroku lucypera musi krzywdę tę nagrodzić roczną służbą.

II. diabelskie prace. diabeł wykonywa serię nadludzkich prac, przypominających wyczyny Heraklesa [...], a więc: (a) karczuje las ścieląc pokotem drzewa, (b) drzewem młóci zboże, (c) orze w mgnieniu oka ogromny łan, (d) podobnie kosi łąkę, (e) chwyta i zabiera dzikiego byka, którego nań wypuszczono, (f) zdobywa czwórkę koni, (g) zabiera faskę pieniędzy i wszystko to oddaje swemu gospodarzowi.

III. rekompensata, (a) zazwyczaj diabeł poprzestaje na wzbogaceniu chłopa dobytkiem zabranym złemu panu, (b) niekiedy jednak porywa i samego pana, zwłaszcza gdy prowokuje go zaklęciem „bodaj mię diabli wzięli”, albo też (c) dziewczynę na weselu (Krzyżanowski, 1962-1963, t. 1, s. 201).

W ludowych realizacjach, jak można zorientować się nawet na podstawie streszczenia wątku, a co potwierdzają zachowane zapisy (np. Jana Świętka, 1893, i Oskara Kolberga, 1875), diabeł nie jest tylko nosicielem zła, ale też reprezentantem wyższego porządku. Chociaż uchodzi za wysłannika piekieł, działa na rzecz zachowania równowagi w świecie, stąd karze grzeszników, kusi do złych uczynków, ale sam nie ma prawa krzywdzić niewinnych ludzi. To właśnie za łakomstwo spotyka go kara polegająca na konieczności odpracowania wyrządzonego zła. Ponadto w finale bajki ludowej zwykle w sposób nagły znika, gdy wywiąże się ze swej roli, gdyż nie może zmienić swego statusu i zostać wśród ludzi, jak dzieje się w omawianym odcinku. Diabeł pozostaje diabłem na zawsze. W filmowej wersji ta wyrazistość świata się rozmywa, mimo że dobro zwycięża. Licho wybiera życie z ludźmi i nie wraca na bagna, gdzie przebywało do tej pory. Sposób pokazania aktywności licha (jak na przyspieszonej taśmie) i motywacji jego działania trywializuje wymowę baśni filmowej. Nawet prezentacja pracy biedaka, który jest chudy jak patyk, podobnie jak jego koń ciągnący pług po kamienistej ziemi, bardziej śmieszy, niż smuci, gdyż zawarto w tym obrazie zbyt wiele elementów parodystycznych - bohaterowie się przewracają, robią dziwne miny, co nie wywołuje ważnego w kształtowaniu postaw humanitarnych współczucia, a jedynie rozbawienie. Odbiorca po zakończeniu odcinka pozostaje z samozadowoleniem, że ekonomiczna sytuacja chłopa się poprawiła, licho dołączyło do rodziny biedaka, a więc dobro zwyciężyło. Jest to jednak zadowolenie konsumpcyjne, powierzchowne, wynikające z przyjemnej chwili spędzonej przed ekranem, czemu nie towarzyszy głębia przeżycia. Zagubiono 
po drodze wpisane w bajki ludowe, a dość dobrze zachowane w baśniach braci Grimm czy Andersena uczucia cierpienia, smutku, rozpaczy, a nawet samotności i grozy. Dopiero spektrum tych doznań pozwala na pełnię doświadczenia i zrozumienie, czym jest życie. Filmowe baśnie lansują proste wartości, które uzyskuje się w równie prosty sposób. W obu odcinkach - i o smoku, i o lichu nie ma też wyrazistej kary dla tych, którzy popełnili wykroczenia, gdyż same wykroczenia również zostały zbanalizowane.

Powyższe uwagi, chociaż krytyczne, jeśli uwzględni się luźny stosunek filmowej adaptacji (nie tylko) do ludowego pierwowzoru, nie zmieniają przekonania, że to bardzo dobrze zrobiony cykl telewizyjny. Wskazane elementy wspólne - jak typ fabuły, wybór podobnych tekstów źródłowych, początkowe i końcowe formuły gawędy, karnawałowa wizja świata, czynią serię przyjemną w odbiorze i z pewnością zapewniają pogodną rozrywkę. Jednocześnie różnorodność stylistyczna, plastyczna i muzyczna przekazów sprawia, że poszczególne odcinki uciekają od stereotypowości twórczej i potrafią odbiorców oswajać $\mathrm{z}$ różnymi formami sztuki. Jednakże pozostaje nieodparte wrażenie, że te piękne, wielokrotnie nagradzane w Polsce i na świecie filmy gubią wyrazistość ocen i postaw, jak też straciły szansę na pokazanie nowych wzorców sprzyjających wyzwaniom ponowoczesności w zakresie społecznym oraz kulturowym. Ucieczka od bajki ludowej, szerzej - od tradycji, w którą wpisana była głębia doświadczeń, także tych negatywnych, aczkolwiek z ludzkiego punktu widzenia potrzebnych, doprowadziła do emocjonalnej pustki i krainy pięknych, choć ulotnych wrażeń - wrażeń filmowych, jednak odległych od codzienności.

\section{Bibliografia}

Adamczak, J. (scen i reż.). (2002). Szklana góra [odcinek serialu telewizyjnego]. W: E. Sobolewska (prod.), Baśnie i bajki polskie. Warszawa: TVP1.

Adamczak, J. (scen i reż.). (2003). O kowalu i diable [odcinek serialu telewizyjnego]. W: E. Sobolewska (prod.), Baśnie i bajki polskie. Warszawa: TVP1.

Adamczak, J. (scen i reż.). (2008). Król kruków [odcinek serialu telewizyjnego]. W: E. Sobolewska (prod.), Baśnie i bajki polskie. Warszawa: TVP1.

Adamczak, J. (scen i reż.), Gałązkowski, J. (reż.). (2009). Poznańskie koziołki [odcinek serialu telewizyjnego]. W: E. Sobolewska (prod.), Baśnie i bajki polskie. Warszawa: TVP1.

Andersen, H. C. (2005). Mała syrenka. W: Baśnie (B. Sochańska, tłum., s. 14-41). Poznań: Media Rodzina. (wyd. oryg. 1837).

Bielski, M. (1551). Kronika wszystkiego świata. Kraków: Helena Unglerowa. Pobrane z: https://polona.pl/item/kronika-wszystkiego-swiata,MTEyMzI1NTg/. 
Bolecki, W. (1989). Od potworów do znaków pustych. Z dziejów groteski. Pamiętnik Literacki, 80(1), 73-121.

Chybowicz-Brożyńska, M. (scen.), Kotecki, Z. (scen. i reż.). (2004). Dwanaście miesięcy [odcinek serialu telewizyjnego]. W: E. Sobolewska (prod.), Baśnie i bajki polskie. Warszawa: TVP1.

Cieliczko, P. (b.d.). Legenda o trębaczu ratuszowym i królu kruków. Pobrane z: http:// poznanskielegendy.pl/krol-krukow-pawel-cieliczko/.

Dyksińska, G. (scen.), Krzysik, Z. (reż.). (2009). Pasterz tysiąca zajęcy [odcinek serialu telewizyjnego]. W: E. Sobolewska (prod.), Baśnie i bajki polskie. Warszawa: TVP1.

Gliński, A. J. (1853). Baśń o królewnie zaklętej w żabę. W: Bajarz polski. Zbiór baśni, powieści i gawęd ludowych (t. 1, s. 73-94). Wilno: Drukarnia Gubernialna.

Gołębiowska-Suchorska, A. (2018). Szewczyk Dratewka. W: V. Wróblewska (red.), Słownik polskiej bajki ludowej (t. 3, s. 225-229). Toruń: WN UMK.

Gosienicki, A. (scen. i reż.). (2009). Szewc Kopytko i kaczor Kwak [odcinek serialu telewizyjnego]. W: E. Sobolewska (prod.), Baśnie i bajki polskie. Warszawa: TVP1.

Grimm, W., Grimm, J. (2010). Roszpunka. W: Baśnie dla dzieci i dla domu (E. Pieciul-Karmińska, tłum., t. 1, s. 73-78). Poznań: Media Rodzina (wyd. oryg. 1812).

Hendrykowski, M. (2013). Adaptacja jako przekład intersemiotyczny. Przestrzenie Teorii, 20, 175-184. https://doi.org/10.14746/pt.2013.20.12.

Jabłońska, E. (scen.), Dudek, A. (reż.). (2004). Smok Wawelski [odcinek serialu telewizyjnego]. W: E. Sobolewska (prod.), Baśnie i bajki polskie. Warszawa: TVP1.

Jabłońska, E. (scen.), Dudek, A. (reż.). (2008). Zimowe wróżki [odcinek serialu telewizyjnego]. W: E. Sobolewska (prod.), Baśnie i bajki polskie. Warszawa: TVP1.

Jabłońska, E. (scen.), Kukuła, A. (reż.). (2004). Bazyliszek [odcinek serialu telewizyjnego]. W: E. Sobolewska (prod.), Baśnie i bajki polskie. Warszawa: TVP1.

Jabłońska, E. (scen.), Turło, R. (reż.). (2005). O królewnie zaklętej w żabę. W: E. Sobolewska (prod.), Baśnie i bajki polskie. Warszawa: TVP1.

Jabłońska, E. (scen.), Turło, R. (reż.). (2009a). Czarne licho. W: E. Sobolewska (prod.), Baśnie i bajki polskie. Warszawa: TVP1.

Jabłońska, E. (scen.), Turło, R. (reż.). (2009b). Dar Skarbnika. W: E. Sobolewska (prod.), Baśnie i bajki polskie. Warszawa: TVP1.

Januszewska, H. (1952). O Bartku-doktorze. W: Baśnie polskie (s. 5-22). Warszawa: Czytelnik.

Januszewska, H. (1955). Złota jabłoń. W: Złota jabłoń (s. 7-29). Warszawa: Czytelnik. Jasińska-Koronkiewicz, J. (scen. i reż.). (2008). Złota jabłoń [odcinek serialu telewizyjnego]. W: E. Sobolewska (prod.), Baśnie i bajki polskie. Warszawa: TVP1.

Kalniuk, T. (2014). Mityczni obcy. Dzieci i starcy w polskiej kulturze ludowej przełomu XIX i XX wieku. Toruń: WN UMK. 
Kędzierski, C. (1989). Trębacz ratuszowy i król kruków. Legenda wielkopolska. Warszawa: Krajowa Agencja Wydawnicza (wyd. oryg. 1929).

Kolberg, O. (1875). Diabeł na zarobku. W: Lud. Jego zwyczaje, sposób życia, mowa, podania, przysłowia, obrzędy, gusła, zabawy, pieśni, muzyka i tańce. Serya VIII. Krakowskie. Część 4. Powieści, przysłowia i język (nr 69, s. 167-169). Kraków: Drukarnia Dr. Ludwika Gumplowicza.

Konieczna, E. (2005). Baśń w literaturze i w filmie. Rola baśni filmowej w edukacji filmowej dzieci w wieku wczesnoszkolnym. Kraków: TAiWPN Universitas.

Krzyżanowski, J. (1962-1963). Polska bajka ludowa w układzie systematycznym (t. 1-2). Wrocław: Zakład Narodowy im. Ossolińskich.

Krzyżanowski, J. (1977). Romana Zmorskiego Sobotnia Góra. W: Paralele. Studia porównawcze z pogranicza literatury i folkloru (wyd. 2 rozsz., s. 729-739). Warszawa: PIW.

Kurek, B. (scen.), Czarzasty, P. (reż.). (2009). Bursztynowa korona [odcinek serialu telewizyjnego]. W: E. Sobolewska (prod.), Baśnie i bajki polskie. Warszawa: TVP1.

Kurek, B. (scen.), Kukuła, A. (reż.). (2009). O Zefliku i smoku [odcinek serialu telewizyjnego]. W: E. Sobolewska (prod.), Baśnie i bajki polskie. Warszawa: TVP1.

Kurek, B. (scen.), Martini-Madej, M. (reż.). (2008). Zuzanka i utopce. W: E. Sobolewska (prod.), Baśnie i bajki polskie. Warszawa: TVP1.

Kwiatkowska, A. (2017). Trębacz ratuszowy i król kruków (Czesław Kędzierski). Wyborcza.pl Poznań. Pobrane z: http://poznan.wyborcza.pl/poznan/56,36001,21460541,trebacz-ratuszowy-i-krol-krukow-czeslaw-kedzierski,1.html?disableRedirects=true.

Lesisz, P. (scen.), Kukuła, A. (reż.). (2008). Kozucha kłamczucha [odcinek serialu telewizyjnego]. W: E. Sobolewska (prod.), Baśnie i bajki polskie. Warszawa: TVP1.

Leszczyński, M. (b.d.). Korale czarownicy. Pobrane z: http://torpan.cba.pl/Serwis/bajki/korale/korale.htm.

Lubieniecka, A. (scen. i reż.). (2005). Zaczarowane pantofelki [odcinek serialu telewizyjnego]. W: E. Sobolewska (prod.), Baśnie i bajki polskie. Warszawa: TVP1.

Lubieniecka, A. (scen. i reż.). (2008). Korale czarownicy [odcinek serialu telewizyjnego]. W: E. Sobolewska (prod.), Baśnie i bajki polskie. Warszawa: TVP1.

Lubieniecka, A. (scen.), Giersz, W. (reż.). (2003). Żywa woda [odcinek serialu telewizyjnego]. W: E. Sobolewska (prod.), Baśnie i bajki polskie. Warszawa: TVP1.

Lubieniecka, A. (scen.), Kasprzycki, J. (rė̇.). (2002). Złota kaczka [odcinek serialu telewizyjnego]. W: E. Sobolewska (prod.), Baśnie i bajki polskie. Warszawa: TVP1.

Lubieniecka, A. (scen.), Kukuła, A. (reż.). (2003). O Bartku doktorze [odcinek serialu telewizyjnego]. W: E. Sobolewska (prod.), Baśnie i bajki polskie. Warszawa: TVP1.

Lubieniecka, A. (scen.), Turło, R. (reż.). (2003). Lodowa góra. W: E. Sobolewska (prod.), Baśnie i bajki polskie. Warszawa: TVP1.

Lubieniecka, A. (scen.), Wrotniewski, A. (reż.). (2003). Szewczyk Dratewka. W: E. Sobolewska (prod.), Baśnie i bajki polskie. Warszawa: TVP1. 
Lüthi, M. (1982). Zabójca smoka. O stylu bajki (J. M. Kasjan, tłum.). Literatura Ludowa, 3, 36-40. (wyd. oryg. 1968).

Ługowska, J. (1981). Ludowa bajka magiczna jako tworzywo literatury. Wrocław: Zakład Narodowy im. Ossolińskich.

Makuszyński, K. (1958a). Bajka o królewnie Marysi, o czarnym łabędziu i o lodowej górze. W: Bardzo dziwne bajki (s. 5-39). Warszawa: Czytelnik. (wyd. oryg. 1916).

Makuszyński, K. (1958b). O tym, jak krawiec, pan Niteczka, został królem. W: Bardzo dziwne bajki (s. 61-76). Warszawa: Czytelnik. (wyd. oryg. 1916).

Makuszyński, K. (1958c). Szewc Kopytko i kaczor Kwak. W: Bardzo dziwne bajki (s. 41-60). Warszawa: Czytelnik. (wyd. oryg. 1916).

Marzec, A. (1994). Edukacja filmowa. W: A. Marzec, S. Rzęsikowski, Edukacja teatralna, filmowa i radiowa na lekcjach języka polskiego w klasach IV-VIII (s. 88-154). Kielce: Wydawnictwo Pedagogiczne ZNP.

Morcinek, G. (1958a). O tym, jak głupi Zeflik był mądrym Zeflikiem. W: Jak górnik Bulandra diabła oszukał. Baśnie śląskie (s. 136-161). Warszawa: Nasza Księgarnia.

Morcinek, G. (1958b). O tym, jak górnik Maślok kramarzył ze Skarbnikiem. W: Jak górnik Bulandra diabła oszukał. Baśnie śląskie (s. 16-28). Warszawa: Nasza Księgarnia.

Morcinek, G. (1958c). O tym, jak Zuzanka poszła w kumy do utopców. W: Jak górnik Bulandra diabła oszukał. Baśnie śląskie (s. 112-124). Warszawa: Nasza Księgarnia.

Murphy, T. P. (2015). From fairy tale to film screenplay: Working with plot genotypes. Basingstoke: Palgrave Macmillan.

Neumann, H. (scen.), Gosienicki, A. (reż.). (2005). Krawiec Niteczka [odcinek serialu telewizyjnego]. W: E. Sobolewska (prod.), Baśnie i bajki polskie. Warszawa: TVP1.

Oleksik, K. (1959). Czarownica znad Bełdan. Warszawa: Nasza Księgarnia.

Oppman, A. (1925a). Bazyliszek. W: Legendy warszawskie (s. 33-52). Poznań, Warszawa, Wilno, Lublin: Ksiegarnia św. Wojciecha.

Oppman, A. (1925b). Złota kaczka. W: Legendy warszawskie (s. 83-93). Poznań, Warszawa, Wilno, Lublin: Ksiegarnia św. Wojciecha.

Osterloff, W. (1946). Kryminalistyka i bajki Grimma. Odrodzenie, 19, 6-7.

Ostrowska, B. (ok. 1923). Szklana góra. Warszawa: Instytut Wydawniczy „Bibljoteka Polska”.

Pieciul-Karmińska, E. (2009-2010). Polskie dzieje baśni braci Grimm. Przekładaniec, 22-23, 80-96.

Porazińska, J. (1939). Kozucha kłamczucha. Warszawa: Wydawnictwo M. Arcta.

Porazińska, J. (1952a). O dwunastu miesiącach. W: Za górami... za lasami... Polskie baśnie ludowe (s. 57-65). Warszawa: Nasza Księgarnia.

Porazińska, J. (1952b). Szewczyk Dratewka. W: Za górami... za lasami... Polskie baśnie ludowe (s. 13-19). Warszawa: Nasza Księgarnia. 
Porazińska, J. (1955). Pasterz tysiąca zajęcy. Baśń małopolska. W: Za trzydziewiąta rzeka. Baśnie ludu polskiego (s. 49-59). Warszawa: Nasza Księgarnia.

Short, S. (2015). Fairy tale and film: Old tales with a new spin. Basingstoke: Palgrave Macmillan.

Siemieński, L. (1845). Smok. W: Podania i legendy polskie, ruskie i litewskie (s. 1). Warszawa: Księgarnia J. K. Żupańskiego.

Smolińska, T. (1987). Z wybranych problemów dawnej i wspótczesnej sztuki opowiadania. Opole: WSP im. Powstańców Śląskich

Szelburg-Zarembina, E. (1966). O Klaruni-koronczarce i zimowych wróżkach. W: Przez różową szybkę (s. 153-159). Warszawa: Nasza Księgarnia.

Śmiałowicz, K. (2016). Relacje między postaciami w filmach animowanych dla dzieci. Ogrody Nauk i Sztuk, 6, 464-478.

Świętek, J. (1893). O dyáble co u chłopa za parobka słuzuł. W: Lud nadrabski (od Gdowa po Bochnię). Obraz etnograficzny (nr 22, s. 341-344). Kraków: Akademia Umiejętności.

Świrko, S. (1984). O Maćku Borkowicu i diable Borucie oraz inne podania i legendy wielkopolskie. Poznań: Wydawnictwo Poznańskie.

TV Studio Filmów Animowanych. (2019). Baśnie i bajki polskie III. Pobrane z: http:// tvsfa.com/kategoria/filmoteka/basnie-i-bajki-polskie-iii/.

TVP ABC. (b.d.). Baśnie i bajki polskie. Pobrane z: http://abc.tvp.pl/20258027/basnie-i-bajki-polskie.

TVP Info. (2010). Zimowe wróżki nagrodzone. Pobrane z: https://www.tvp. info/3275318/kultura/zimowe-wrozki-nagrodzone/.

Uther, H.-J. (2011). The types of international folktales: A classification and bibliography (t. 1-3). Helsinki: Suomalainen Tiedeakatemia. (wyd. oryg. 2004).

Waksmund, R. (1992). Baśń. W: A. Brodzka, M. Puchalska, M. Semczuk, A. Sobolewska, E. Szary-Matywiecka (red.), Słownik literatury polskiej XX wieku (s. 90-92). Wrocław: Zakład Narodowy im. Ossolińskich.

Waksmund, R. (2000). Od literatury dla dzieci do literatury dziecięcej (tematy - gatun$k i-k o n t e k s t y)$. Wrocław: Wydawnictwo UWr.

Wolne Lektury. (2011). Z naszej bajki. Pobrane z: https://wolnelektury.pl/info/z-naszej-bajki/.

Wójcicka, M. (2016-2018). Adaptacja bajki ludowej. W: V. Wróblewska (red.), Bajka Ludowa. Stownik. Pobrane z: https://bajka.umk.pl/slownik/lista-hasel/haslo/?id=214.

Wójcicka, M. (2018). Adaptacja bajki ludowej. W: V. Wróblewska (red.), Słownik polskiej bajki ludowej (t. 1, s. 16-25). Toruń: WN UMK.

Wróblewska, J. (2018). Muzyka w filmach o Harrym Potterze. W: M. Wróblewski, S. Kołos (red.), Dziecko w świecie ruchomych obrazów (s. 145-163). Toruń: WN UMK. 
Wróblewska, V. (2014). „Od potworów do znaków pustych”. Ludowe demony w polskiej literaturze dla dzieci. Toruń: WN UMK.

Wróblewska, V. (2018a). Smok Wawelski. W: V. Wróblewska (red.), Słownik polskiej bajki ludowej (t. 3, s. 193-197). Toruń: WN UMK.

Wróblewska, V. (2018b). Wanda. W: V. Wróblewska (red.), Słownik polskiej bajki ludowej (t. 3, s. 287-290). Toruń: WN UMK.

Zadurska, O. (2017). Ludowy wizerunek dzieci kalekich i jego społeczne konsekwencje. Litteraria Copernicana, 3(23), 53-66. https://doi.org/10.12775/LC.2017.050.

Zdzitowiecka, H. (1972). Bursztynowa korona. W: Bursztynowe baśnie (s. 32-36). Gdańsk: Wydawnictwo Morskie.

Zielewiczówna, Z. (1914). Trębacz na ratuszu. Ballada z XVI. wieku w 3 aktach. Poznań: Drukarnia i Księgarnia św. Wojciecha.

Zmorski, R. (1852). Sobotnia Góra. W: Podania i baśni ludu w Mazowszu (z dodatkiem kilku szlaskich $i$ wielkopolskich) (s. 1-19). Wrocław: Zygmunt Schletter.

Zrzeszenie Kaszubsko-Pomorskie. (2019). Akademia bajki kaszubskiej. Pobrane z: http://www.akademiabajkikaszubskiej.pl/.

Żmichowska, N. (1907). Prządki. Powieść ze wspomnień dziecinnego wieku. Warszawa, Kraków: Gebethner i Wolff, Gebethner i Spółka. (wyd. oryg. 1845). 